\title{
Evaluation of the flexural strength and surface roughness of dental material after
}

\section{immersion in coffee}

\author{
Avaliação da resistência à flexão e rugosidade superficial de resina odontológica após imersão em \\ café
}

Evaluación de la resistencia a la flexión y la rugosidad de la superficie de la resina compuesta dental después de la inmersión en café

Received: 01/29/2021 | Reviewed: 02/04/2021 |Accept: 03/09/2021 | Published: 03/17/2021

Patricia Capellato

ORCID: https://orcid.org/0000-0002-6397-5820 Universidade Federal de Itajubá, Brazil E-mail: pat_capellato@yahoo.com.br

Ana Paula Rosifini Alves Claro

ORCID: https://orcid.org/0000-0003-3353-4247 Universidade Estadual Paulista Júlio de Mesquita Filho, Brazil E-mail: paula.rosifini@unesp.br

\begin{abstract}
This study was done in order to evaluate the changes in flexural strength and surface roughness in dental material restorations after immersion in coffee. Bars specimens $(2 \mathrm{~mm}$ x $2 \mathrm{~mm}$ x $25 \mathrm{~mm}$ ) of Z100 3M/ESPE were made according to ISO 4049 using aluminum molds. After curing, the specimens were then randomly divided into five groups and conditioned at $37^{\circ} \mathrm{C}$ in physiological serum. In all groups, except control, samples were immersed in coffee for ten minutes daily. In group A, the samples were immersed in coffee. For group B, after to be immersed in coffee, samples were immersed in distilled water for one minute. For group C, samples were immersed in mouthwash for one minute. For group D, samples were brushing for ten minutes, with load of $250 \mathrm{~g}$ and 4250 cycles after all treatments the samples were stored in physiological serum again. In control group, samples were only stored in physiological serum. The five groups were then divided into 2 subgroups according storage time, six and nine weeks, respectively. Flexural strength was determined using three point bending test in a universal testing machine. All the tests were carried out at a room temperature and samples were maintained in physiological serum during the test. Surface roughness measurements were made using a surface roughness tester. All data were analyzed using one-way analysis of variance (ANOVA) followed by Dunnet tests. The ANOVA indicated no difference in the means of surface roughness and significant was observed for flexural strength between control group and one group (coffee).
\end{abstract}

Keywords: Flexural strength; Dental materials; Surface roughness.

\section{Resumo}

Este estudo foi realizado com o objetivo de avaliar as alterações na resistência à flexão e rugosidade superficial em restaurações de materiais odontológicos após imersão em café. Amostras de barras ( $2 \mathrm{~mm}$ x $2 \mathrm{~mm}$ x $25 \mathrm{~mm}$ ) de Z100 3M / ESPE foram feitas de acordo com a ISO 4049 usando moldes de alumínio. Após a cura, as amostras foram divididas aleatoriamente em cinco grupos e acondicionadas a $37^{\circ} \mathrm{C}$ em soro fisiológico. Em todos os grupos, exceto o controle, as amostras foram imersas em café por dez minutos diários. No grupo A, as amostras foram imersas em café. Para o grupo B, após serem imersas no café, as amostras foram imersas em água destilada por um minuto. Para o grupo $\mathrm{C}$, as amostras foram imersas em enxaguatório bucal por um minuto. Para o grupo D, as amostras foram escovadas por dez minutos, com carga de $250 \mathrm{~g}$ e 4250 ciclos, após todos os tratamentos as amostras foram armazenadas novamente em soro fisiológico. No grupo controle, as amostras foram armazenadas apenas em soro fisiológico. Os cinco grupos foram então divididos em 2 subgrupos de acordo com o tempo de armazenamento, seis e nove semanas, respectivamente. A resistência à flexão foi determinada usando um teste de flexão de três pontos em uma máquina de teste universal. Todos os testes foram realizados à temperatura ambiente e as amostras foram mantidas em soro fisiológico durante o teste. As medições da rugosidade da superfície foram feitas usando um testador de rugosidade da superfície. Todos os dados foram analisados usando análise de variância unilateral (ANOVA) seguida de testes de Dunnet. A ANOVA não indicou diferença nas médias de rugosidade superficial e foi observada significância para resistência à flexão entre o grupo controle e o grupo A (café).

Palavras-chave: Resistência à flexão; Materiais dentários; Rugosidade. 


\section{Resumen}

Este estudio se realizó con el fin de evaluar los cambios en la resistencia a la flexión y la rugosidad de la superficie en restauraciones de material dental después de la inmersión en café. Las probetas de barras ( $2 \mathrm{~mm}$ x $2 \mathrm{~mm}$ x $25 \mathrm{~mm}$ ) de Z100 3M / ESPE se realizaron según la norma ISO 4049 utilizando moldes de aluminio. Después del curado, las muestras se dividieron al azar en cinco grupos y se acondicionaron a $37^{\circ} \mathrm{C}$ en suero fisiológico. En todos los grupos, excepto el control, las muestras se sumergieron en café durante diez minutos diarios. En el grupo A, las muestras se sumergieron en café. Para el grupo B, luego de sumergirse en café, las muestras se sumergieron en agua destilada durante un minuto. Para el grupo C, las muestras se sumergieron en enjuague bucal durante un minuto. Para el grupo $\mathrm{D}$, las muestras se cepillaron durante diez minutos, con una carga de $250 \mathrm{~g} 4250$ ciclos después de todos los tratamientos, las muestras se almacenaron nuevamente en suero fisiológico. En el grupo de control, las muestras solo se almacenaron en suero físiológico. Los cinco grupos se dividieron luego en 2 subgrupos según el tiempo de almacenamiento, seis y nueve semanas, respectivamente. Lo módulo de ruptura se determinó utilizando una prueba de flexión de tres puntos en una máquina de prueba universal. Todas las pruebas se realizaron a temperatura ambiente y las muestras se mantuvieron en suero fisiológico durante la prueba. Las mediciones de la rugosidad de la superficie se realizaron utilizando un medidor de rugosidad de la superficie. Todos los datos se analizaron mediante el análisis de varianza de una vía (ANOVA) seguido de pruebas de Dunnet. El ANOVA indicó que no hubo diferencias en las medias de rugosidad de la superficie y se observó una resistencia a la flexión significativa entre el grupo de control y el grupo uno (café).

Palabras clave: Resistencia flexional; Materiales dentales; Rugosidad de la superficie.

\section{Introduction}

The increase of the life expectancy associated to modern life habits, as fast food, ingestion of pigmented drinks, as coffee, the use of cigarette, etc., has generated new challenges for the dentists and the professionals of this area. Nowadays, the dentists come across functional and aesthetic factors that challenge the materials and the techniques that must adapt to this new reality. Besides, along the life time there is the physiologic wear of the teeth, in other words, the teeth decrease due to the masticatory attrition, and this fact is inevitable. The dentist needs to give back the original format of the teeth, being careful in preserving the remaining dental element.

The composed resin is used since 1960 however, it was starting from the acid of the enamel conditioning, the development of the adhesive system and of the BisGMA molecule in the decade of 1970 that these aesthetic restoring materials had significant progresses. The adhesive system made possible that the cavities to be restored got smaller, because they don't need retention and resistance forms.

Dental composites may be defined as combinations of at least two chemically different materials with a distinct interface. Dental resin composites consist of a resin matrix (organic phase), inorganic filler particles (dispersed phase), fillermatrix coupling agent (interface), and minor additions including polymerization initiators, stabilizers and coloring pigments. Similar to other composite structures, the type and composition of the resin matrix as well as the filler particles have strong influence on the mechanical properties, which ultimately determines the clinical performance of these materials (Tsujimoto et al., 2018).

Several authors have evaluated the resin properties and others verified that for some resins, the immersion means may alter their mechanical properties such as: hardness, flexural strength, and fracture toughness. However, due to the aesthetic importance of these materials, studies evaluating the influence of color stability has been accomplished. (Alvanforoush et al., 2017b; Camilotti et al., 2021b; Rodrigues et al., 2020)(Alvanforoush et al., 2017a; Camilotti et al., 2021a; Lorenzetti et al., 2015).

Then, some studies have concluded the immersion od the resin in acid environment alter some of their properties. Also, the aesthetic of the resin is a important factor. So, the correlation between color stability and toothbrushing have been investigated under influence of several means (Badra et al., 2005; Camilotti et al., 2021a; Lai et al., 2018; Leite et al., 2010; Phanestu \& Syafiar, 2018; Somacal et al., 2020). However, it is unknown whether simulated intraoral environmental associated 
coffee might also adversely affect dental composite properties (Alvanforoush et al., 2017a; Badra et al., 2005; Camilotti et al., 2021a, 2021b; Donmez et al., 2021; Hwang et al., 2018; Lai et al., 2018; Leite et al., 2010; Lin et al., 2017; Phanestu \& Syafiar, 2018; Ruivo et al., 2019; Somacal et al., 2020; Tsujimoto et al., 2018).

The purpose of this study was to compare the flexural strength of resin composite after immersion in different media. The hypothesis tested was the media would adversely affect composite flexural properties.

The coffee was chosen, because Brazil is one of the largest producers of the world and its population is a big consumer of this drink. In the literature, the period of immersion in a general way corresponds to thirty days, and the option for nine weeks is justified once it corresponds to the double of the time; a plastic sieve was used to remove and to put the samples back in the pot with physiologic serum and a tweezers to put them in the brushing machine to avoid the manual contact with the samples. The immersion period in the coffee was ten minutes, because it was taken into account that the ingestion of a cup corresponds to one minute of contact with the teeth/resin, the average ingestion is ten cups a day. The methodology developed looked for a way to diminish the possible effects caused by the coffee, they were: water, mouthwashes and brushing.

\section{Methodology}

For this study one hundred samples were manufactured using an aluminum molds, bars ( $25 \mathrm{~mm}$ x $2 \mathrm{~mm}$ x $2 \mathrm{~mm}$ ) were fabricated from a dental composite restorative (Z100, 3M ESPE, USA) according to the norm ISO 4049. The manufacturing of the samples was carried following the methodology: molds were positioned over a glass slide. After application of resin into one, a second glass slide was pressed over the surface in order to extrude excess material. The surfaces of the samples were then light polymerized in three overlapping irradiations of $40 \mathrm{~s}$ and output intensity of $470 \mathrm{~mW} / \mathrm{cm} 2$ (Figure 1).

Figure 1 - (a) Sample used in tests; (b) aluminum mold.

a)

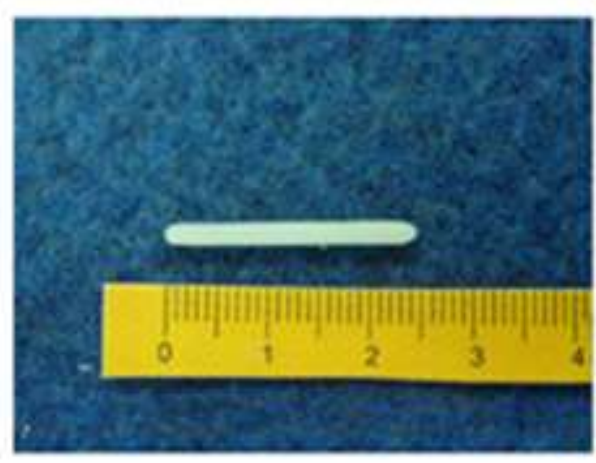

b)

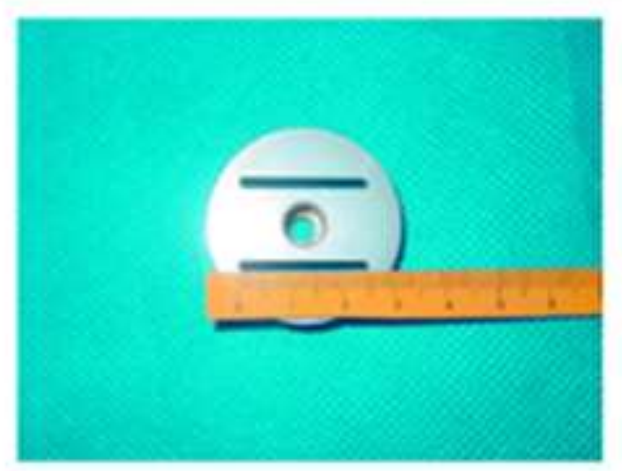

Source: Authors.

After curing the specimens were then randomly divided into five groups and conditioned at $37 \square \mathrm{C}$ in physiological serum. The following cycles was taken for every sample group daily: The A B C and D groups were immersed in $100 \mathrm{ml}$ of coffee for ten minutes aiming to simulate the daily ingestion of coffee. However, for each group samples were submitted for one condition after coffee. For the group A, the samples were immersed in coffee and stored in physiological serum again. For the group B, after the immersion in coffee the samples were immersed for one minute in $200 \mathrm{ml}$ of distilled water and taken back in aquarium. For the group C, the same procedure of group B was followed but a mouthwash. For the group D, after the immersion in coffee the samples were brushed (Figure 2). 
Figure 2 - Aquarium to simulated oral environment conditioned at $37^{\circ} \mathrm{C}$ in physiological serum; Coffee to simulate the daily ingestion of coffee; Distilled water to immersed Group B; and, mouthwash to immersed Group C.

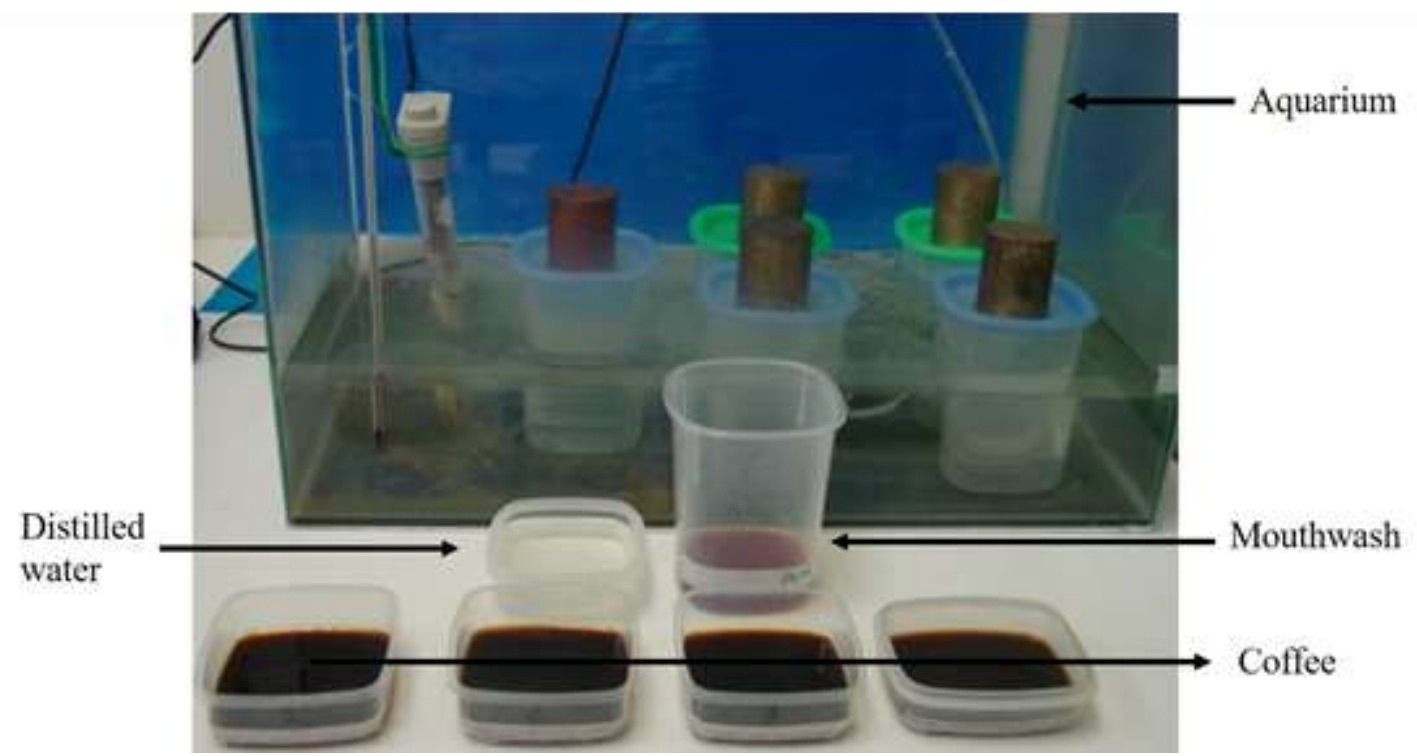

Source: Authors.

To simulate the daily tooth brushing of the patient a standard machine was applied. The machine consisted of a base on which there were two round devices where the matrix was inserted, two arms held two Oral B tooth brushes with a load of $250 \mathrm{gr}$ on the bristles. The sample were submitted to 4250 daily cycles, 10 minutes, at 140 cycles/minute (Figure 3 ). A Colgate toothpaste was used added to water at a 1/1 rate. For every group the samples were taken out of the aquarium on the 6th and 9th weeks. The coffee use was prepared using a standard procedure of $24 \mathrm{gr}$ of ground coffee and $400 \mathrm{ml}$ of water.

Figure 3 - Machine used to simulated the brushing at Group D.

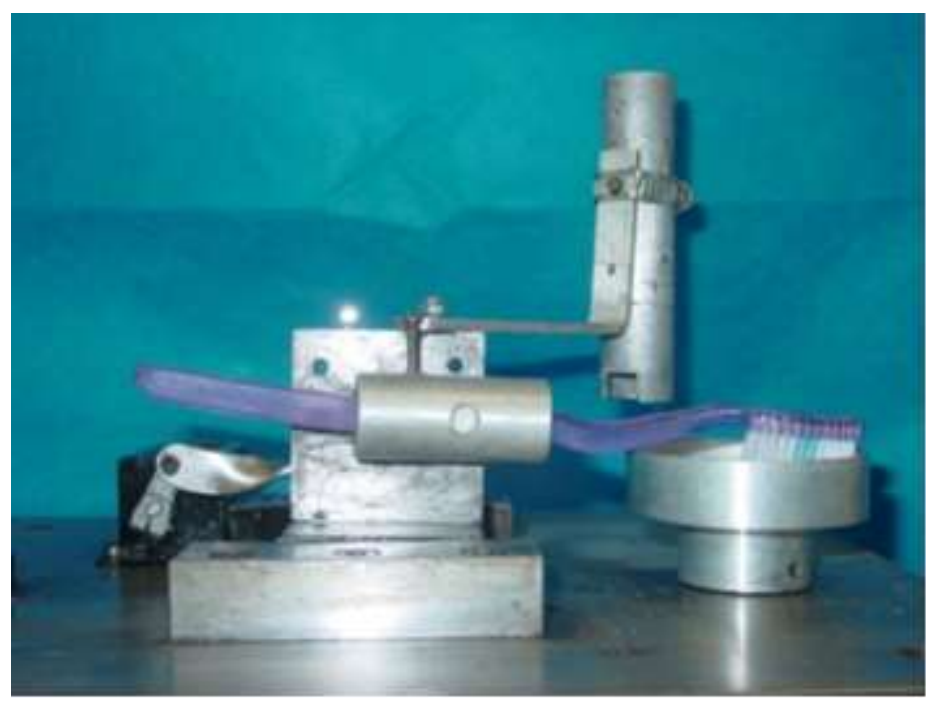

Source: Authors.

\section{Mechanical Characterization}

\section{Three point bending test}

To accomplish the flexural strength by the three point bending test was used with a device developed by Dias (2002)(Figure 4) (Oksman et al., 2002). Such device allows the storage of the samples in physiologic serum during the 
accomplishment of the test. A piece with supports is fit in its interior on which the sample is placed during the test, the distance between supports is $7 \mathrm{~mm}$. The test was performed with a Universal Testing Machine (Versat 2000, Panambra, Brazil) at a crosshead speed of $0.5 \mathrm{~mm} / \mathrm{min}$; the load at fracture was recorded and maximum flexural strength was calculated using the following formula:

$$
\sigma=\frac{M C}{I}
$$

where $\sigma$ is the flexural strength, $\mathrm{L}$ the span length, $\mathrm{h}$ the specimen thickness, $\mathrm{b}$ the specimen width and $\mathrm{F}$ is the maximum load applied.

Figure 4 - a) Universal Testing Machine (Versat 2000, Panambra, Brazil) and b) samples in physiologic serum during the accomplishment of the test.

a)

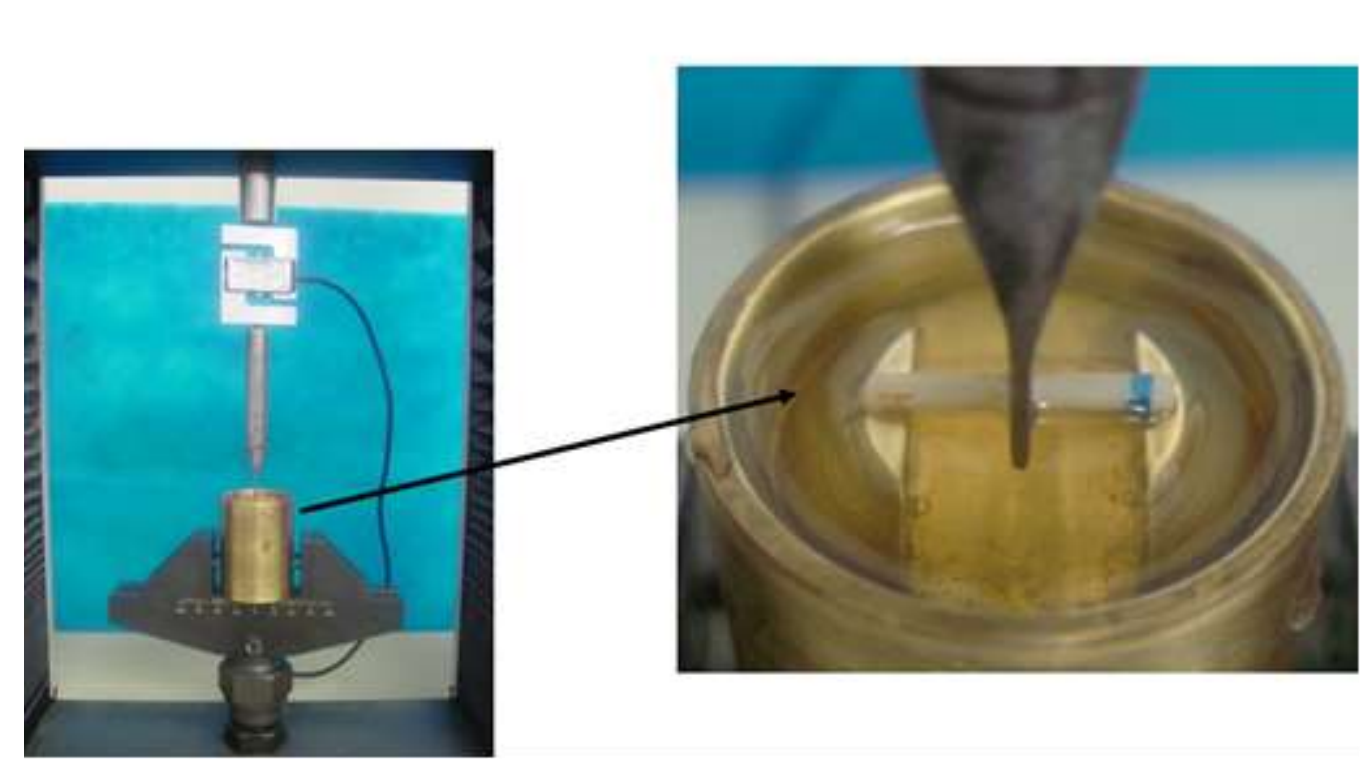

Source: Authors.

b)

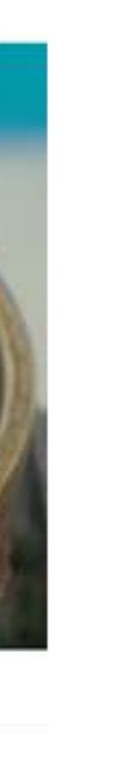

\section{.}

\section{Surface roughness measurement}

Surface roughness measurements were made using a surface roughness tester (Mitutoyo). Five roughness average were made for each sample after 6 and 9 weeks.

\section{Statistical analysis}

These data were analyzed using one-way analysis of variance (ANOVA) followed by Tukey's multiple comparison tests.

\section{Results and Discussion}

The influence of the coffee on the flexural strength and the surface roughness were appraised. The samples were submerged for a period from 6 to 9 weeks in physiologic serum and submitted the immersion in Group A, B, C, D and control during ten minutes daily. The flexural tests were accomplished according to the norm ISO 4049 and during the test care was 
taken to keep the samples in the physiologic serum, to avoid the dehydration.

The results obtained after the accomplishment of the flexural resistance test for groups A (coffee), B (coffee and water), $\mathrm{C}$ (coffee and mouthwash), D (coffee and brushing) and control group can be observed at Table1.

Table 1 - The mean flexural strength values for specimens after different periods of immersions.

\begin{tabular}{|c|c|c|}
\hline \multicolumn{3}{|c|}{ Flexural strenght (Mpa) } \\
\hline Time & 6 weeks & 9 weeks \\
\hline Group control & $3952+-17,26$ & $41,75+-4,57$ \\
\hline Group A & $29,99+-5,61$ & $25,10+-1,45$ \\
\hline Group B & $25,57+-8,76$ & $43,21+-7,03$ \\
\hline Group C & $31,92+-4,32$ & $29,91+-1,53$ \\
\hline Group D & $22,44+-7,15$ & $35,26+-10,66$ \\
\hline
\end{tabular}

Source: Authors.

In the analysis control group was the one with the greatest dispersion in 6 weeks $(\mathrm{SD}=17.26)$ and the Group $\mathrm{C}$ the least dispersed $(\mathrm{SD}=4.32)$; in 9 weeks, the Group D group had the highest dispersion $(\mathrm{SD}=10.66)$ while the Group A group $(\mathrm{SD}=1.45)$ the lowest dispersion. ANOVA showed no statistically significant difference between groups for 6 weeks $(\mathrm{F}=$ 1.35 ; $\mathrm{p}>0.05)$. For 9 weeks, ANOVA showed a statistically significant difference between the groups $(\mathrm{F}=4.71 ; \mathrm{p}<0.05)$. Dunnett's test was selected to compare between which groups there is a difference, and revealed that the statistical difference was between the Group control X Group A ( $\mathrm{p}<0.05)$. There was no significant difference between all groups for 6 weeks. However, a significant decrease in flexural strength was identified for coffee group compared control group after 9 weeks. The results are the according with another author's study.

The mean surface roughness values ( $\mathrm{Ra}$ e $\mathrm{Rz}$ ) for specimens after different periods of immersion are summarized in Table 2 .

Table 2 - The mean surface roughness values ( $\mathrm{Ra}$ and $\mathrm{Rz}$ ) for specimens after different periods of immersions.

\begin{tabular}{|c|c|c|c|c|}
\hline \multicolumn{5}{|c|}{$\begin{array}{c}\text { Surface } \\
\text { Roughness }(\mu \mathrm{m})\end{array}$} \\
\hline Time & \multicolumn{3}{|c|}{6 weeks } & Rzeeks \\
\hline Mean & $\mathrm{Ra}$ & $\mathrm{Rz}$ & $\mathrm{Ra}$ & $\mathrm{Rz}$ \\
\hline Group & & & & 17,88 \\
\hline control & 7,79 & 28,97 & 5,51 & 18,81 \\
\hline Group A & 8,32 & 28,97 & 5,51 & 22,46 \\
\hline Group B & 6,88 & 41,04 & 3,81 & 23,92 \\
\hline Group C & 6,93 & 31,24 & 3,06 & 12,77 \\
\hline Group D & 8,73 & 29,42 & 3,04 & \\
\hline
\end{tabular}

Source: Authors. 
Table 2 shows the means of the roughness of each group at the times of 6, and 9 weeks. Ra roughness the Control group showed the greatest dispersion both in 6 weeks and in 9 weeks ( $\mathrm{SD}=4.70$ and $\mathrm{SD}=3.63$, respectively), the lowest dispersion was observed in the Group A in 6 weeks and in the Group C at 9 weeks. ANOVA showed no statistically significant difference between groups for either 6 or 9 weeks $(F=0.31 ; p>0.05)$ and $(F=1.06 ; p>0.05$, ) respectively. For the $R z$ roughness, the Group $\mathrm{C}$ showed the highest dispersion in both 6 and 9 weeks $(\mathrm{SD}=12.53$ and $\mathrm{SD}=11.40$, respectively), the lowest dispersion was observed in the Group A at 6 weeks and in the Group B in 9 weeks. ANOVA showed no statistically significant difference between groups for either 6 weeks or 9 weeks $(F=1.56 ; p>0.05)$ and $(F=0.78 ; p>0.05)$, respectively.

For the surface roughness tests significant differences were not verified among the groups. Those results were contrary the those obtained other studies (Badra et al., 2005; Camilotti et al., 2021b; Hwang et al., 2018; Phanestu \& Syafiar, 2018). However, those authors used artificial saliva associated to the coffee as mean of immersion and, besides, it was observed in their studies that the isolated effect of the saliva increased the roughness, therefore, the coffee didn't influence that property, but it is believed that in the mentioned studies the influence was due the saliva and not to the coffee.

\section{Conclusion}

Based on the results we can conclude there were no significant statistical changes after 6 weeks. There were significant statistical changes after 9 weeks between the coffee and control groups and the means used to diminish the coffee effects (distilled water, mouthwash and brushing) showed significant statistical results after 9 weeks.

\section{References}

Alvanforoush, N., Palamara, J., Wong, R., \& Burrow, M. (2017a). Comparison between published clinical success of direct resin composite restorations in vital posterior teeth in 1995-2005 and 2006-2016 periods. Australian Dental Journal, 62(2), 132-145. https://doi.org/10.1111/adj.12487

Alvanforoush, N., Palamara, J., Wong, R. H., \& Burrow, M. F. (2017b). Comparison between published clinical success of direct resin composite restorations in vital posterior teeth in 1995-2005 and 2006-2016 periods. In Australian Dental Journal. 62(2), 132-145. Blackwell Publishing. https://doi.org/10.1111/adj.12487

Badra, V. V., Faraoni, J. J., Ramos, R. P., \& Palma-Dibb, R. G. (2005). Influence of different beverages on the microhardness and surface roughness of resin composites. Operative Dentistry, 30(2), 213-219.

Camilotti, V., Mendonça, M. J., Dobrovolski, M., Detogni, A. C., Ambrosano, G. M. B., \& De Goes, M. F. (2021a). Impact of dietary acids on the surface roughness and morphology of composite resins. Journal of Oral Science, 63(1), 18-21. https://doi.org/10.2334/josnusd.19-0518

Camilotti, V., Mendonça, M. J., Dobrovolski, M., Detogni, A. C., Ambrosano, G. M. B., \& De Goes, M. F. (2021b). Impact of dietary acids on the surface roughness and morphology of composite resins. Journal of Oral Science, 63(1), 18-21. https://doi.org/10.2334/josnusd.19-0518

Donmez, M. B., Olcay, E. O., \& Demirel, M. (2021). Influence of coloring liquid immersion on flexural strength, Vickers hardness, and color of zirconia. Journal of Prosthetic Dentistry. https://doi.org/10.1016/j.prosdent.2020.11.020

Hwang, S., Chung, S., Lee, J.-T., Kim, Y.-T., Kim, Y., Oh, S., \& Yeo, I.-S. (2018). Influence of Acid, Ethanol, and Anthocyanin Pigment on the Optical and Mechanical Properties of a Nanohybrid Dental Composite Resin. Materials, 11(7), 1234. https://doi.org/10.3390/ma11071234

Lai, G., Zhao, L., Wang, J., \& Kunzelmann, K. H. (2018). Surface properties and color stability of dental flowable composites influenced by simulated toothbrushing. Dental Materials Journal, 37(5), 717-724. https://doi.org/10.4012/dmj.2017-233

Leite, V. M. F., Pisani, M. X., Paranhos, H. F. O., Souza, R. F., \& Silva-Lovato, C. H. (2010). Effect of ageing and immersion in different beverages on properties of denture lining materials. Journal of Applied Oral Science, 18(4), 372-378. https://doi.org/10.1590/S1678-77572010000400009

Lin, J., Ozan, S., Munir, K., Wang, K., Tong, X., Li, Y., Li, G., \& Wen, C. (2017). Effects of solution treatment and aging on the microstructure, mechanical properties, and corrosion resistance of a $\beta$ type Ti-Ta-Hf-Zr alloy. RSC Advances, 7(20), 12309-12317. https://doi.org/10.1039/c6ra28464g

Lorenzetti, M., Kulkarni, C. V., Iglič, A., Patil-Sen, Y., Junkar, I., \& Kulkarni, M. (2015). Wettability studies of topologically distinct titanium surfaces. Colloids and Surfaces B: Biointerfaces, 129, 47-53. https://doi.org/10.1016/j.colsurfb.2015.03.024

Oksman, K., Wallström, L., Berglund, L. A., \& Toledo Filho, R. D. (2002). Morphology and mechanical properties of unidirectional sisal-epoxy composites. Journal of Applied Polymer Science, 84(13), 2358-2365. https://doi.org/10.1002/app.10475

Phanestu, T. H., \& Syafiar, L. (2018). Surface Roughness of Nanofiller Composite Resin after Immersion in Black Tea. 225-229. https://doi.org/10.2991/idsm-17.2018.30 
Research, Society and Development, v. 10, n. 3, e30510312486, 2021

(CC BY 4.0) | ISSN 2525-3409 | DOI: http://dx.doi.org/10.33448/rsd-v10i3.12486

Rodrigues, M. M., Fontoura, C. P., Dotta Maddalozzo, A. E., Leidens, L. M., Quevedo, H. G., Souza, K. dos S., da Silva Crespo, J., Michels, A. F., Figueroa, C. A., \& Aguzzoli, C. (2020). Ti, $\mathrm{Zr}$ and Ta coated UHMWPE aiming surface improvement for biomedical purposes. Composites Part B: Engineering, 189, 107909. https://doi.org/10.1016/j.compositesb.2020.107909

Ruivo, M. A., Pacheco, R. R., Sebold, M., \& Giannini, M. (2019). Surface roughness and filler particles characterization of resin-based composites. Microscopy Research and Technique, 82(10), 1756-1767. https://doi.org/10.1002/jemt.23342

Somacal, D. C., Manfroi, F. B., Monteiro, M. S. G., De Oliveira, S. D., Bittencourt, H. R., Borges, G. A., \& Spohr, A. M. (2020). Effect of pH cycling followed by simulated toothbrushing on the surface roughness and bacterial adhesion of bulk-fill composite resins. Operative Dentistry, 45(2), $209-218$. https://doi.org/10.2341/19-012-L

Tsujimoto, A., Barkmeier, W. W., Fischer, N. G., Nojiri, K., Nagura, Y., Takamizawa, T., Latta, M. A., \& Miazaki, M. (2018). Wear of resin composites: Current insights into underlying mechanisms, evaluation methods and influential factors. In Japanese Dental Science Review. 54(2), 76-87. Elsevier Ltd. https://doi.org/10.1016/j.jdsr.2017.11.002 